\title{
STUDIES IN KURDISH HISTORY
}

\section{By G. R. Driver, Magdalen College, Oxford}

[At the beginning of these articles the writer desires to express his obligations to Professor D. S. Margoliouth for much assistance and especially for giving him access to the unpublished sheets of his edition of $I b n$ Miskarraih, and to Shaikh M. H. 'A bd-ur-râziq for many references in the Arabic historians, especially in the Kâmil of Ibn-ul-A thîr.]

\section{The Origin and Character of the Kurns}

LTHOUGH even at the present day nothing is certain in regard A to the origin of the Kurds, even less was known to ancient writers, whose accounts are purely mythical. They were, however, generally so little studied that speculation on this question does not seem to have become common until a comparatively late period, and even then to have been almust exclusively confined to eastern scholars. The solitary exception from this rule is Strabo, the Greek geographer of the last century before Christ, who in his article on Gordiæa, a district probably to be identified with a part of Kurdistân, provides an eponymous hero, Gordys the son of Triptolemus, as the ancestor of the Gordyæi. ${ }^{1}$

The Arabic writers on the subject are more explicit. Mas' îdî, the geographer, who lived and wrote in the middle of the tenth century, gives a fairly full account of their origin, but is careful to point out that he regards such theories as tentative, and in part as purely legendary. He prefaces his statements by warning the reader that there is no certainty on such a subject and then offers the information which he has amassed for what it is worth. According to some authorities, he says, the Kurds are descended from Rabî́ah ibn Nizâr ibn Ma'add ibn 'Adnân ibn Bakū ibn Wầil. At a very early date they separated themselves from the Arabs in consequence of certain events, which are left unmentioned, and settled in the mountains and valleys near the towns of Persia and elsewhere. There they forgot their original speech and adopted a foreign language, and since then each tribe has spoken its own peculiar dialect. Others, however, claim that the Kurds are sprung from Muḍar ibn Nizâr and are of the

1 Strabo, Geographica, xvi, 1, 25, p. 747, and xvi, 2, 5, p. 750, which is copied by Stephanus Byzantinus, Ethnica (ed. Meineke), vol. i, p. 211.

VOL. II. PART III. 
race of Kurd ibn Mard ibn Șa'șa'ah ${ }^{1}$ ibn Hawâzin, and that they migrated from their own original home, wherever that may bave been, in the distant past as the result of their quarrels with the Ghassânî. Others, again, add that they are the descendants of Rabî'ah and Mudar, who withdrew into the mountains in search of water and pasturage and abandoned their native language owing to their contact with strangers; and this is supposed to account for their preference for a life among the mountain ranges of Persia and Kurdistân. This last is the story which Mas' ûdî regards as the most probable, apparently because it agrees with the traditions handed down from immemorial ages among certain tribes living as far apart as Syria and Adharbaijân. But he adds two other legends which he has heard in the course of his inquiries. The first of these is that some trace their ancestry back to slave-girls belonging to King Solomon. When this monarch, the story ran, was deprived of his crown, certain of these girls, who were infidels, bore children by a demon named Jasad; Solomon, on his restoration by God to royal power, learnt of these children whom the demon had begotten and drove them forth ${ }^{2}$ into the mountains and valleys, together with their mothers. There they increased and multiplied exceedingly, and became the ancestors of the Kurdish race. The last version given by Mas' $\hat{u} d \hat{\imath}$ is quite different. According to it there was once a tyrant named Daḥ̣âk dhu-'l-Afwâh on whose shoulders there had grown two serpents which fed upon human brains. The Persians, infuriated at the massacres perpetrated by the followers of Dahhâk in the endeavour to keep the serpents supplied with their proper diet, raised a considerable force, at the head of which they put the jinn 'Afrîdûn. This 'Afrîdûn seized Dahhâak and banished him to Mount Danbâwand, but the tyrant's chief minister succeeded daily in slaughtering a man and a ram, whose blood he mixed and fed thereon the two serpents. Finally those Persians who escaped this fate fled into the mountains and adopted the lives of savages; and there they married and bore children, by whom they became the parents of the Kurds. ${ }^{3}$

I In Kurd ibn Mard it is clear that Kurd is a fictitious eponymous hero, but the supposed descent from Mard may be due to a recollection of some connexion with the ancient Mardi (see vol. ii, pt. ii, p. 200 of this Bulletin).

2 The Arabic word for "drove forth" here used is karrada, from the rootkard; the story, which is due to the similarity of sound between Kurd and kard, is merely an example of populiur etymology.

3 Mas'ûdî, Murîj-udh. Dhahab (ed. de Meynard and de Courteille), vol. iii, ch. xlvi, pp. 249-53. The same author elsewhere gives several variants, claiming that the founder of the Kurdish race was Kurd ibn Isfandiyâdh ibn Manûshahr 
Turning from the regions of mythology to those of ethnology, the historian finds scarcely less uncertainty in the theories put forward by the early inquirers on the racial connexions of the Kurds. Abu-'l-Fidâ, himself a Kurd, states that he has heard it claimed that the Kurds were Arabs or Nabataeans, while others held them to be Persian Arabs, from the similarity between their manner of living and that of the ordinary nomad Arab; but he seems himself to class them with the Jîlî and the Dailamî as a Persian race. ${ }^{1}$ Ibn Baṭ̂tâa, the traveller, records that he was told in Persia that the Kurds were of Arab origin, ${ }^{2}$ in which view Ibn-ul-Athîr concurs. ${ }^{3}$ Other opinions are those of Abu-'l-Faraj, who identified the Kurds with the Lurs, ${ }^{4}$ and of some Armenian writers, who seem to have confused the Kurds and the Medes. ${ }^{5}$

The Kurds must certainly be connect?d with the Kardûchi mentioned in Xenophon and the Gordyæi mentioned in other Greek and Latin authors, with the Kordukh or Kortschaikh of the Armenians and the land of Gardin of the Aramaic and Syriac writers. It seems also very likely that, even if they do not go back to the old Persian race of Iranian origin, they at least are closely related to the modern Persians. Their language, kurmanj $\hat{\imath}$, is a palois of Persian, which it still closely resembles and which proclaims clearly their Iranian origin. in speech and racial characteristics the Kurds are related to the

or Kurd ibn Mard ibn Șa'șa'ah ibn Harb ibn Hawâzin, or that they are the issue of Sabî‘ ibn Hawâzin or of Bakr ibn Hawâzin, while others believed that their first parent was called Rabî‘ or Bakr ibn Wâ'il (At-Tanbîh wa-'l-Ashrâf, ed, de Goeje, in Bibliotheca Geographorum Arabicorum, vol. viii, pp. 88-91).

Ibn Khallikân mentions two variant forms of the legend, according to one of which the ancestor of the Kurds was a king of Yaman named 'Amr-ul-Muzaikiyah who migrated into Persia and according to the other Kurd ibn 'Amr ibn Âmir (Wafayāt-ul-A'yân, ed. de Slane, vol. iii, pp. 514-15).

The story of the serpents, allegorized into tumours, is repeated in Al-Ansârî (Nukhbat-ud-Dahr, ed. Charmoy, p. 19), and that deriving the Kurds from 'Amr king of Yaman in the Qâmûs (vol. i, p. 682).

1 Abu-'l-Fidâ, At-Tawâkîkh-ul-Qadîmah (ed. Fleischer), vol. iv, p. 145.

2 Ibn Batutâ, Voyages (ed. Defrémery and Sanguinette), vol. ii, pp. 22-3.

${ }^{3}$ Ibn-ul-Athîr, At-T'Arîkh fi-'l-Kamil (ed. Tornberg), vol. i, p. 70.

+ Abu-'l-Faraj, Târîkh-ud-Duwal (ed. Pococke), p. 564. This error is probably caused by the presence of a large Kurdish element in the population of Luristân (QÂmûs, loc, cit.), where it is said that the Kurds were the dominant element at the time of its invasion by the Shāh 'Abbâs I in A.D. 1606. The Lurs are now thought to be aboriginal Persians with an admixture of Semitic blood in their veins; their language is a dialect of Persian and does not differ materially from Kurdish, which is also a patois of Persian.

5 See Haitun (Recueil des Historiens des Croisades, Docunnents Arméniens), vol. ii, pp. 225, 343-4. The same writer seems to imply in several passages that Media was the proper home of the Kurds (ibid., pp. 127, 267). 
Lurs, but the two races are in no wise to be identified with them, in spite of the statement, quoted above, of Abu-'l-Faraj. The following table of the various branches of the Iranian languages will approximately illustrate the racial affinities of the Kurds ${ }^{1}$ :--

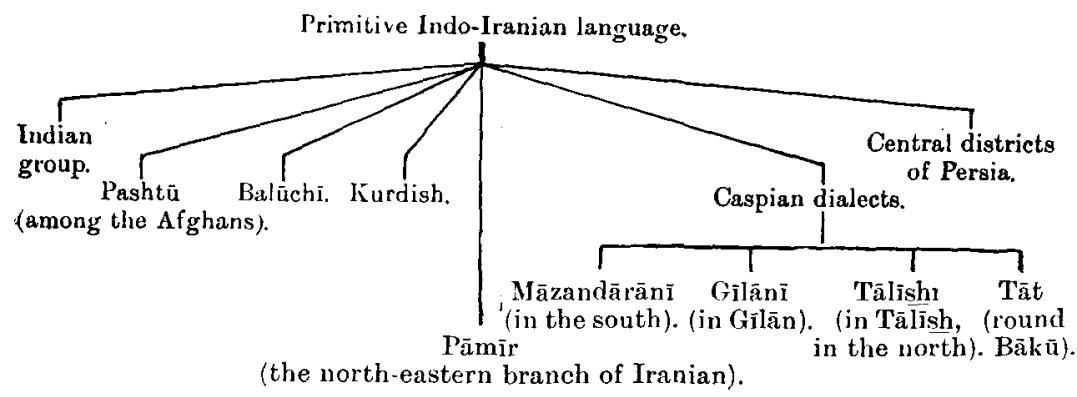

To form a correct estimate of the numbers of the Kurds is an impossibility, but various conjectures have been made by travellers, while others have endeavoured to compile figures from the utterly unreliable statistics of the Turkish Empire. Réclus put the total at 1,800,000 in A.D. 1884, but Socin has disputed this figure as being far too high. ${ }^{2}$ Quatremère estimated the Turkish Kurds at 1,650,000, the Persian Kurds at 800,000 , and those in Russia at 50,000. ${ }^{3}$ The writers in the Encyclopcedia Britannica put the number of Kurds in Caucasia at 99,836, from the figures returned in the latest available statistics of the Russian Empire. ${ }^{4}$ In north-western Persia there are said to be some 800,000 or 900,000 Sunnî Muslims, of whom the majority are Kurds, ${ }^{5}$ while no statistics based on a racial system appear to be available for Turkey; but the followers of the various creeds in Asia Minor, Kurdistân, and Armenia at the last census were found to be 10,030,000 Muslims, 1,144,000 Armenian Christians, $1,818,000$ Christians of other denominations, and 249,000 Jews, exclusive of a miscellaneous body of adherents of diverse unimportant creeds. ${ }^{6}$

- See Hirt, Die Indogermanen, vol. i, pp. 99-113, from whom this table is copied. See also E. B. Soane, "Notes on the Phonology of Southern Kurmanji" in the Journal of the Royal Asiatic Society, 1922, pp. 191-226, and the opinions of Justi, Darmesteter, and Socin there cited.

2 Réclus, Nonvelle Geographie, p. 342.

${ }^{3}$ Quatremère, Notices et Extraits des Manuscrits dans la Bibliothèque du Roi (Paris), vol. xiii, pp. 305 ff.

4 Encyclopadia Britannica, Caucasia, vol. v, p. 548, and Russia, vol. xxiii, p. 874 .

5 Ibid., Persia, vol. xxi, p. 199.

6 Ibid., Turkey, vol. xxrii, p. 427. 
Another estimate for Northern Kurdistân is given in the following statistics of the six Armenian Provinces of Turkey, compiled in 1912 by the Armenian Patriarchate of Constantinople ${ }^{1}:-$

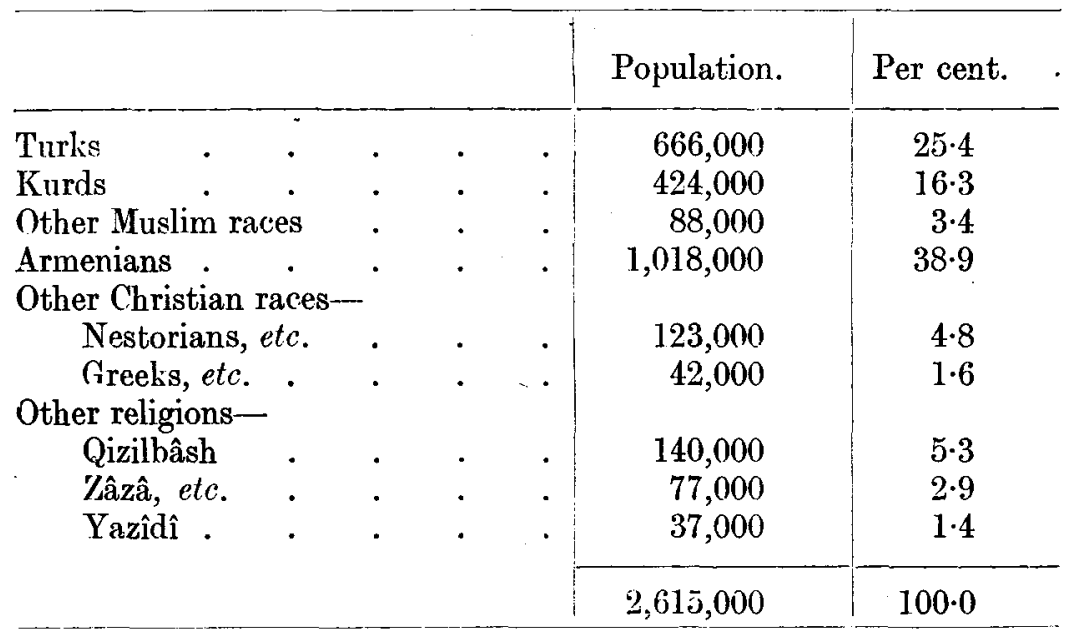

According to Turkish statistics, the total population of the six provinces is $3,528,400$. The Kurdish population is much underrated by the Armenian Patriarchate; a Russian estimate in 1914 gave the number of Kurds in the two wilâyat of Wân and Bidlîs as about 473,000 .

The latest statistics for the population of Mesopotamia are the following 2 :-

\begin{tabular}{|c|c|c|c|c|c|}
\hline Arabs & . & . $1,450,000$ & Armenians & . & 57,000 \\
\hline Kurds & & 380,000 & Yazîdî & . & 21,000 \\
\hline Turks and & d Turkmans & 110,000 & Chabaks . & . & 10,000 \\
\hline Persians & 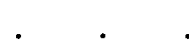 & 70,000 & Gircassians & . & 8,000 \\
\hline Jews & . & 60,000 & Şabians & . & 2,000 \\
\hline Syrian $\mathrm{Ch}$ & hristians & 60,000 & Miscellaneous & . & 10,000 \\
\hline
\end{tabular}

\section{Total . . . 2,238,000}

The Kurds are split up into countless tribes, of three hundred of which Mas' ûdî is said to have recorded the names, and these again ${ }^{3}$ are divided into numerous sub-tribes, clans, and families. ${ }^{4}$ Some of these

${ }^{1}$ See Armenia and Kurdistân (No. 62 of the "Handbooks prepared under the direction of the Foreign Office "), p. 7.

2 See Mesopotamia (No. 63 of the "Handbooks prepared under the direction of the Foreign Office "), p. 8.

3 Al-Ansârî, Nulkhbat-ud-Dahr (ed. Charmoy), p. 19.

4 The technical names for the tribes and their subdivisions are the following: 'ashîrah, large tribe ; qabîlah, moderate-sized tribe ; țâ'ifah, clan ; khhânah, 'tent' or family living in a fixed residence; ahl châdîtî, or ahl khaimah, tent-dwellers; 
tribes live a nomad and others a settled life, in spite of many attempts to induce the former to settle down and occupy themselves with farming and other forms of agricultural life. Idrîs, the lieutenant of the Sultan Salîm I (A.D. 1502-20), in pacifying Kurdistân after the conquest of that country, found the rich arable lands almost deserted and the mountains bristling with the castles of independent chieftains of various races, between whom there still burnt the flames of age-long feuds. He therefore compelled the Kurds to settle on the vacant lands and divided the country into sanajiq governed by Turkish officials and, in the more inaccessible parts of the hill-country, by the local chiefs. This policy gave rest indeed to the land, but favoured that growth of Kurdish influence and power which is reflected in the pages of Sharaf-ud-Dîn's history and which was always to be a source of anxiety to the Turkish Government. It was not, however, until the middle of the last century that the Kurds began to show any real signs of abandoning their nomad manner of life. ${ }^{1}$

When Kurds and Armenians occupy adjacent territory, the former are almost invariably found occupying the high ground, while the latter cling to the valleys and especially to the cities. But the hill-tribes generally descend to the lower slopes and plains in winter, when on account of the cold the heights become uninhabitable both by man and beast. The two races, however, remain unabsorbed by the surrounding Turks, for whom both alike evince the utmost detestation. The attitude of the Kurd towards his neighbours is well reflected in some of his popular sayings. Many proverbs, e.g. "like the word of a Turk" and "as importunate as the Turkish taxes", express his contempt for the lying Turk and his hatred for the oppressive administration of his government. The Armenian he regards in the same light as that in which the European looks upon the proverbial "dirty Jew", and this spirit is exemplified by reference to the petty huckster as a person "with finger-nails like an Armenian". The Arab he dislikes as a common plebeian, saying of him : "do not unduly encourage an Arab or he will come and defile your cloak," and : the Arab is like a fly; the more you drive him away, the more insistent he becomes." The Persian receives in like manner a measure of good-natured scorn; "like a Persian sword," which is double-edged and therefore able to

$k \hat{u} \underline{c h a r}$, nomads; akinjî, settled labourer. The terminations $-\hat{a} n,-\hat{\imath},-\hat{a} n \hat{\imath},-l \hat{\imath}$, or $-l \bar{u}$ are usually attached to the tribal names (Jaba, Recueil de notices et Récits Kourdes).

1 For the results of compelling nomads to lead a sedentary life see Sir M. Sykes, The Last Heritage of the Caliphs, pp. $403 \mathrm{ff}$. 
strike friend and foe indiscriminately, and "as effete as the Persian army " are both maxims referring to his unreliable character. ${ }^{1}$

In spite, however, of the carefully preserved distinctions of race, ${ }^{2}$ there are a few mixed Turkish and Kurdish tribes, chiefly in Cilicia, where Kurds and Turkmân tribes have similar customs and manners and often live together with a common tribal organization. The principal mixed tribes are Barbas-'Ashîrâti, the Turkmân-Sirkintlî, the Kurd-Jarîd, the Karsant-'Ashîrâti, and the Manamanjî-'Ashîrâti. Both races were nomad until forced by the government about sixty years ago to build villages and adopt a more orderly mode of life ; but the nomadic instinct is still strong within them, and often impels them to leave their homes and wander. Their occupation is still principally the tending of flocks and herds on the slopes of the mountains, and very few have as yet settled in the towns and villages of the plains ; those who have done so for the most part live as pedlars or earn a precarious livelihood by smuggling tobacco. They seldom work for hire, and their sole industry is the weaving of coarse rugs and mats. In character these mongrel Kurds are harsh and cruel and easily roused to fanaticism, though they are described as having a strict sense of honour; those in whom the Turkmân blood flows more strongly are said to exhibit a kindlier disposition. But it is not improbable that the intermingling of distinct races, as is often the case, has brought out the worst characteristics of both. The women go unveiled and are allowed great freedom, but most of the hard manual labour falls on them. Many of these Cilician Kurds migrate to the plains in the harvest season, often going as far as Diyârbakr in search of casual employment, and for this purpose they assemble in the markets of Tarsus, 'Adânah and other cities, and hire themselves out to the local farmers on weekly contracts.

The testimony of all ancient writers about the habits and character of the ordinary Kurd is unanimous. Then as now they were savages, dwellers in the mountains, steppes and valleys, tenders of oxen, sheep, and horses, " behaving, as do the Arabs and Turks, like cattle and, like cattle, trampling on whatever they possess," in the words

1 Quoted from Noel, "The Character of the Kurds as illustrated by their Proverbs and Popular Sayings," in the Bulletin of the School of Oriental Studies, vol. i, pt. iv, pp. 79-90.

2 It is said that many of the Kurds in Armenia practise mutilation or disfigurement of the head with a view to emphasizing their distinction from the surrounding peoples (Encyclopadia Britannica, under Mutilation, vol. xix, p. 100), but the present writer has been unable to find any confirmation of this statement 
of an anonymous Syriac writer. ${ }^{1}$ Another writer refers to their churlish disposition, ${ }^{2}$ and Mas' $^{\prime}$ ûdî mentions that they were in his day a pastoral people, who recalled their scattered herds in the mountains by blowing a kind of rough wind-pipe. ${ }^{3}$ Many a traveller also who has gone on his way among them, from Xenophon and the Ten Thousand Greeks onwards, has warned his readers against their predatory habits. Ibn Jubair enters a special caution against those in the Jazîrah, whose territory he crossed and whom he calls " a pest from Mauṣil to Naṣîîin and Dunaișar, committing highway robbery and busied in ruining the country"." At-Tanukkhî, writing in the eleventh century, tells how his caravan was plundered by a party of Kurds, who took whatsoever they could find, ${ }^{5}$ and Al-Hamadânî seems almost to regard the name "Kurd" as synonymous with "robber" in a passage in one of his epistles, where the only distinction that he can draw is that, whereas robbers despoil the aukitf, or pious benefactions bequeathed for the use of the poor, the Kurd only robs the weak. ${ }^{6}$ Nor do modern explorers differ from the opinions expressed by their predecessors, and Marco Polo calls them "an evil generation, whose delight it is to plunder merchants ". 7

Oppression of the weak and treachery, then, were the characteristics which attracted the attention of ancient writers. And that they were not averse from over-reaching their neighbours, over whom fortune had given them the upper hand, is well shown by the following story. Ibn-ul-'Amîd told the Arabic historian Ibn Miskawaih that he and Rukn-ud-Daulah were in A.D. 951 caught by some Kurds in an awkward position, whence they could not extricate themselves, and were in the utmost distress from lack of provisions for themselves, their soldiers, and their beasts, none daring to show himself outside the camp. All supplies had been cut off, and the only food obtainable had to be purchased from individual Kurds who brought it into the camp by night and sold it at extortionate prices. A Kurd would come with a sack, nose-bag or other vessel, containing flour and sell it; but when he had gone on his way with the price in his

${ }^{1}$ Causa Cansarim, written in the eleventh or twelfth century (ed. Kayser), p. 676 (=Syr. 150 , Germ. 194).

${ }^{2}$ Al-Yâqûbî, Al-Buldân, in Bibliotheca Geographorum Arabicorum (ed. de Goeje), vol. vii, p. 236.

${ }^{3}$ Mas'ûdî, Murúj-zth-Dhahab, vol. viii, ch. 122, p. 90.

4 Ibn Jubair, Rihalah (ed. de Goeje), p. $240(=141)$.

5 At-Tanûkhî, An-Nishwâr (ed. Margoliouth), p. 190.

6 Al-Hamadânî, Epistles (ed. Bairût), p. 172.

${ }^{7}$ Marco Polo, Tracels (ed. Yule), vol. i, p. 62. 
purse and the sack was emptied, it was found as often as not that the amount of flour which they had seen in it barely covered the surface, all beneath being earth. Thus they did with wheat also and barley, playing many tricks of a similar nature on their helpless victims. ${ }^{1}$ In other cases, indeed, it was found that not even the chiefs could refuse a bribe, according to the statement of Ibn-ul-Athîr, and many perchance deemed it advisable to pacify them with a gift. ${ }^{2}$

Such being the character that they bore, it is not surprising to find that the name Kurd became a term of abuse, and At-Tabarî has preserved examples of this usage, wherein a man reproached his enemy with the taunts " $O$ thou Kurd, brought up in the tents of the Kurds ", 3 and " $O$ thou son of an harlot, reared in the tents of the Kurds", 4 as the bitterest and most shameful insults at his command. And the feeling of the Arab for his turbulent neighbour can be divined from the eastern equivalent of the English saying. "when Greek meets Greek", the Arabic proverb that "a Kurd will scoff at a soldier"."

It is, however, as soldiers and mercenaries that, the Kurds have generally been most esteemed. ${ }^{6}$ Among the ancients they were ever accounted, as in the days of Xenophon, excellent slingers ${ }^{7}$ and archers $^{8}$; yet a study of their history serves but to show that they invariably proved unreliable, even as the Sultan 'Abd-ul-Ḥamîd (A.D. 1876-1909) lately found them. For he took the rash step of enrolling some in a body of irregular cavalry, called the hamid $\hat{\imath}_{y}\left(i h{ }^{9}\right.$ for service both as troops and as police, while others were enlisted in the cheté, which was little more than an organized band of brigands for use in the Balkan wars. This hamîdîyah, however, was of very little use ; for in the war of A.D. 1877-8 it never went into action, being entirely occupicd in collecting loot; and, when a general mobilization for manouvres was ordered, it had to be abandoned owing to the passive resistance of the Kurds, who refused to report themselves for duty in an undertaking from which they saw no chance of reaping any profit. The

${ }^{1}$ Ibn Miskawaih, Tajârib-ul-Umam (ed. Margoliouth), vol. ii, p. 140.

2 Ibn-ul-Athîr, op. cit., vol. ix, p. 263.

3 At-Tabarî, Annals (ed. Nöldeke), p. 11.

Ibid., p. 279.

5reytag, Arabum Proverbia, vol. iii, p. 398.

- See the Syriac Life of Mär Yabhalâhât (ed. Bedjan), ch. xviii, pp. 186-7, and ch. xix, p. 201, for their employment as hired infantry.

7 Suidas, Lexicon (ed. Gaisford), vol. ii, p. 1979.

8 Haitun praises the skill of the Kurds round Mârdin as archers (Documents: Arméniens, loc. cit., rol. ii, pp. 131-2).

${ }^{9}$ Sir M. Sykes, The Last Days of the Caliphate, pp. 420-1. 
organization aimed at winning the affections of the tribes by allowing them extraordinary licence under a semi-military guise; its officers could only be tried by a regular court martial, and in any conflict with the civil authorities they were invariably supported by the Sublime Porte. The only consequence of these privileges was an increase in lawlessness, and one of the darkest stains in Kurdish history is the facility with which these people allowed themselves to become the tools of the Young Turks in carrying out the Armenian atrocities.

The nomadic habits of the Kurd are bad for the development of the land; for not only do they not allow them to practise agriculture themselves, but they also inculcate in them a contempt for those who have settled down, and their continual depredations on their more civilized neighbours make farming so hazardous and unprofitable that many a fertile tract of country now lies waste. At the same time it must be admitted that the inefficiency of the Turkish civil occupation has offered no hope of security to those who would fain settle permanently on the land. Though in some parts the Kurds have become sedentary and work on the soil, they are thoughtless for the morrow, while ignorant distrust of modern appliances is crowned by oriental indifference to progress. One of the main causes of this inveterate nomadism is perhaps to be sought in the love of horses, which they breed in vast herds in the highlands of Armenia and which force them to travel much; for the horse, which is born high in the hilly country, has to be brought down to the plains in winter for the sake of the milder climats. Besides the rearing of horses, the Kurds keep sheep and goats in vast numbers but, unlike the Arabs, no camels; for the camel can only live in the plains, while the Kurd shuns the hot low-lying sandy wastes which are the Arab's home. The sedentary Kurd grows every kind of farm-produce, while those who dwell in the cities are weavers and smiths; but these also, and especially those who occupy the smaller villages in the hills, are lawless and addicted to robbery; and they pay their taxes only at irregular intervals or elude them entirely, for many are ready to revert to nomadism if an opportunity offers itself. When, however, Kurdish families have been working on the land for several generations, they often constitute the finest class in the country. They are sturdy, capable men, and frequently enlist in the army or the police. In the lower districts they are now becoming peaceful citizens, but those who live in the more remote districts, and in particular the inhabitants of the mountainous country between 'Irâq and Persia, are still hardly subject to any control. 
These latter spend the winter from October to February in villages or in camps in the plains on the eastern bank of the Tigris. In March the semi-nomads move into tents until the harvest is over, and in June they migrate with their flocks and herds to the lofty pastures on the mountain-plateaux from the Argut Dâgh to the Aurumân Dâgh; the pure nomads leave the plains somewhat earlier, before the harvest. Similar movements take place from the plain of Mausil to the high tablelands round lake Wân, between which and Hamadân they are able to live in comparative plenty. These tribes, both nomadic and semi-nomadic, eke out their somewhat scanty living by exacting blackmail from their sedentary neighbours and from passing travellers and, if hard pressed by the local anthorities, do not shrink from seeking refuge across the frontier. In Luristân and Persia proper the Kurds grow corn, especially round Kirmânshâh, and live a sedentary life; they are, notwithstanding, hardy fighters. The summer they spend in tents beside their villages or on the roofs of their houses for the sake of the cool air, only in the winter retiring into the warmth of their cottages. Their villages also are often fortified with a strong blockhouse for defence against less peaceful tribes. ${ }^{1}$

The tribal tie, though very weak among the urban Kurds, is a powerful bond of union amongst all other classes, exerting its greatest force among those whose lives are completely nomadic. But small parties frequently break away from the larger whole in order to join other groups; for no hesitation is felt by a tribe in receiving additions to its numbers. The small tribes are of little importance and only act through the orders of the main body. Each tribe is controlled by an 'agh $\hat{t}$ or chief, whose power depends ultimately on his qualifications for holding office, although he relies also on the support and influence of his near relations, who form a kind of advisory council and by the loss of which he is rendered powerless. Yet the authority of a chicf has often been paralysed by an obstinate minority, which can only be coerced at, the expense of a blood-feud which is at all costs to be avoided, for the inevitable result is the weakening and often the virtual extermination of the whole tribe. In some cases a religious significance is attached to the chiefs, who in consequence usually exercise a wider sway beyond the limits of their own tribe. The Muslim Kurdish chiefs of Sulaimâniyah, for instance, are invested with a religious authority which confers on its holders a wide secular

1 On the natural and commercial products of Kurdistân see the present writer's article in the Asiatic Review, vol, xvii, No. 52, pp. 695-700. 
power. As a general rule the 'agh $\hat{a}$ must belong to one family, although the office is not strictly hereditary. On the death of a chief the headmen of the tribe meet to elect his successor, paying careful attention to the candidate's fitness to rule. If they disagree, the result often is that the tribe breaks up and the various parties unite with other tribes in the neighbourhood or migrate to a different locality.

Public opinion in a tribe only sets towards the preservation of tradition, by which all are bound. The only sanctions of tribal society are ancient custom and the blood-feud, and it is regarded as an honourable duty to carry on the feud until full vengeance has been exacted. This spirit is reinforced by such proverbs as: "The enemy of the father will never be the friend of his son" and : "Do not leave the account with your enemy unsettled," 1 which every Kurd is taught in earliest childhood. Nevertheless, before the aggrieved party has recourse to such a feud, a private dispute is generally referred to the chief or to a holy man or to the tribal council for arbitration; but the dissatisfied litigant will often set the award aside and open a feud by murdering his opponent. A quarrel may, however, be settled by the payment of a sum of money, though this course is apt to be regarded as tantamount to a confession of weakness and therefore to be avoided. But it is important to bear in mind that all such feuds are laid aside for an indefinite period in face of a common danger menacing the whole tribe. Yet there are other laws making for security of life, of which the foremost is the duty to a guest or to a tribesman who throws himself on a man's protection. These ordinanaces would indeed prove an intolerable burden were it not for the restraint which prevents a man from adopting such a course except in the direst extremity. An equally favourable point in the character of the Kurd is his high ideal of the sanctity of marriage, in which he stands on a higher plane than the Muslim. Kurdish women are comparatively free to come and go as they like; they are wooed and won by open courtship, for in almost all tribes they are unveiled. In the resulting union the wife plays no secondary part and is regarded as "the pillar of the house". Most Kurds marry early in the hope, it is said, of living to enjoy the company of grown-up children, upon whom they look as "the fruit of the house ", according to a Kurdish popular saying. The morality of their women is famous, and almost all tribes punish adultery with death ; prostitution is almost unknown, and it is even asserted that 
there is no word in Kurdish for a prostitute, who is called a "Persian woman " in the east, a "Russian" in the north, and a "Turk" in the west of Kurdistân. ${ }^{1}$

The courage of the Kurd is undisputed, and it has been inculcated in him from earliest youth that "arms are but half the battle ", while death, or at least death in battle, is hardly feared. Their love of independence has struck all-observers from Xenophon, who has recorded that the Kardûchi were not subject to the king of Persia but apparently autonomous," down to Gibbon, who calls them "a people hardy, strong, savage, impatient of the yoke, addicted to rapine and tenacious of the government of their national chiefs " 3 ; and Major Noel records as one of their most time-honoured adages : "Do not knock at anyone's door and no one will knock at yours." The last-mentioned writer adds that they are clean livers, to whom unnatural vices are unknown, addicted neither to the use of alcohol nor of opium, and that over-indulgence at the table is strongly condemned. Their pleasures are simple and all connected with the flesh, "which they eat, which they ride, and with which they sleep." They have also a shrewd appreciation of the practical value of wealth, even though adversity has taught them its snares. Of religion they do not think much, and most references to it and to its professors in their proverbs are supercilious or mocking. Their treachery the same writer considers to be really the result of the hard conditions under which they live, the constant and bitter inter-tribal feuds, and of the fact that their country has been for centuries overrun by invaders who have never shown sympathy with or consideration for its inhabitants, while their practical turn of mind tends to convey a sense of callousness to people who are not themselves orientals. $^{4}$ But these points, although they should be thrown into the scale in forming a just estimate of the national character of the Kurd, can hardly be accounted an adequate excuse for the countless acts of treachery, of robbery and of murder with which the pages of their history are stained. Of the arts of civilization and of literature, as of political ability, the Kurds have none. They have never organized the administration of their own country, nor have they

1 Noel, loc. cit.

2 Xenophon, Anabasis, V, v, 17.

${ }^{3}$ Gibbon, The Decline and Fall of the Roman Empire, ch. lix.

4 Noel, op. cit. For the character of the modern Kurds see also Sykes, The Last Heritage of the Caliphs, Rich, Narrative of a Residence in Koordistan, and Millingen, Wild Life among the Kurds. 
shown any capacity for cohesion between the varied tribes whose aggregate forms the Kurdish nation. The only Kurd, the illustrious Saladin, who was able to form an empire strong enough to defy the western world relied on Arab arms and Muslim fanaticism rather than on the loyalty of his own kith and kin. And the kingdom thus formed did not long survive its creator; for the quarrels which seem ineradicable among Kurds were kindled into flames among his sons immediately after their father's death and brought about the speedy dissolution of his life-work. And so, to account for the remarkable phenomenon of the sudden rise of the house of Aiy ûb and its equally sudden downfall, the modern historian is tempted to suspect the presence of other than purely Kurdish blood in the veins of the great champion of Islâm.

The opinions expressed by Rich agree with those of other authorities. Writing after long residence in Kurdistân, ${ }^{1}$ he said that from what he had seen of Kurdish gentlemen both at Baghdâd and in their own country, he was inclined to think very favourably of their manners and their hospitality, althongh he found their habit of staring at strangers very disconcerting. They are eager for information and always ready to talk on politics, the affairs of England and France interesting them particularly ; but they are diffident of themselves. Though not usually boisterous among themselves, they are given frequently to emitting loud shrieks for no apparent reason. Bold but unscientific horsemen, they twist, turn, and pull their horses without mercy, and ride hard, whatever the nature of the ground, thereby making their horses restless, vicious, and bad-tempered.

In physique the Kurd is well-made and active, very like the Persian in general appearance. The face is oval, the features sharp, and the nose prominent; the mouth and chin are somewhat receding, the eyes deep-set, dark, and intelligent; the brow is ample and clear, slightly receding; but on the whole the features are more delicate than those of the Persians, especially the hands and fingers, which are small and slender. The women are very pretty when young, but their features become sharp like those of men when only in their prime and their beauty soon withers. They are almost always unveiled, the use of the veil being exceptional and restricted to certain tribes; they are not in the least degree cautious to hide themselves and even admit male servants into their houses, and, although

1 Rich, op. cit. (1836). Amongst his books in the British Museum, it should be added, is a still unpublished Târikh-ul-Akrâd which he obtained in Kurdistân. 
some of the women wear veils of black horsehair, it is rarely pulled down over the face except by women of high rank or when it is desired to ignore anyone's presence. They are treated as equals by their husbands and regard with contempt the slavish estate of Turkish women. But it is not unknown for a chief to force poor parents to bestow on him their daughter for temporary gratification, and then to divorce her or marry her to a servant in order to make way for another wife. Another noticeable feature in their character on which the same writer has remarked is their pride in their ancestry and the attachment of all classes to their chiefs, whom they will follow even into exile. But the chief never hides his sense of superiority to his subjects, nor does the subject either resent this attitude or dare to infringe upon the prerogatives which belong of right to the chief.

It remains but to mention the attainments of the Kurds in literature, and this will not long detain the reader, for they have no written language. They speak, as has already been said, kurmânj $\hat{\imath}^{1}$ a patois of Persian, which is supplemented to a certain extent with words borrowed from Arabic to express ideas unfamiliar to the native Kurd. ${ }^{2}$ Of this there are several dialects, notably that of the Muqrî Kurds, ${ }^{3}$ the Auromânî dialect on the Turco-Persian frontier opposite Baghdad, and the Gûrânî dialect. This latter, though a dying language, is still spoken by the Aurumânî, Rîjâb and Kandûlah tribes and by sections of the Sinjâbî, Gûrânî, and Bâjilân tribes, but it is gradually giving place to kurmánjî. It is, however, not strictly a Kurdish language like-luurmânj $\hat{\imath}$ which has its own distinct grammatical forms, vocabulary, and idiom, but merely a variant of old Persian, perhaps long separated from the mother-tongue, yet one which has also borrowed freely from lourmânjî; of all the dialects it is probably the least affected by modern Persian, whereas on the contrary it borders closely on the dialect of the northern Lurs, But its most interesting point is its connexion with Zâzâ, the degraded, semi-barbarous speech of certain low, almost undeveloped, classes of Kurds in central

1 A noteworthy peculiarity of the Kurd is his tendency to clip words; e.g., Mammü for Mahmûd, Shamsdînân for Shams-ud-Dînîn.

${ }^{2}$ See E. B. Soane, Kermanji Grammar, Yosef Pasha, Dictionnaire KurdeArabe (Stambul), and Schindler, Beiträge zum Kurdischen Wortschatze in the Zeitschrift der Deutschen Morgenländischen Gesellschaft, vol. xlii, pp. 73-9, for works dealing with the language.

3 See O. Mann, Kurdisch-Persische Forschungen: Ergebnisse einer von 1901 bis 1903 in Persien ausgefiihrten Forschungsreise, of which the first part deals with the Muquî dialect. 
Kurdistân. Zâzê is not a kurmânjî language at all from which, however, owing to its own inadequacy to express any but the simplest ideas, it has been compelled largely to borrow. It is, in fact, an archaic survival, and seems to be entirely unaffected by the modern Persian speech. ${ }^{1}$

With these limitations of speech it is not surprising to find that the Kurds have failed to develop a national literature or to show any interest in literature. To this rule the Aiyûhî Kurds form an exception. To Saladin poems were addressed on various occasions ${ }^{2}$; a certain Ibn 'Unain, who had been banished from Damascus, obtained permission from Al-'Âdil to return by composing in that prince's honour a beautiful elegy, ${ }^{3}$ and Tâj-ul-Mulîk, Saladin's nephew, is praised by the Arabic biographer as a man of talent, who published an anthology of his own poems, some of which were good and some of slight merit ${ }^{4}$; Saladin's son Al-Afdual assisted his tutor Al-Bandahî to obtain many rare and valuable books, ${ }^{5}$ while the tomb of Al-Ashraf at Damascus became a library. ${ }^{6}$ But it must be remembered that all these works were composed in Arabic, and it was probably their Arabic upbringing and culture that led the Aiyûbî Kurds to appreciate such things. In legal studies, too, the Kurds were equally backward, only two famous jurisconsults being mentioned by Ibn Khallikân; these are Taq1̂-ud-Dîn ibn-uṣ-Șalâh of Shahrapîr, of the Shâfi' sect, who died at Damascus in A.D. $1245,{ }^{7}$ and 'Tsa the Hakkârî, who died in A.D. $1189 .{ }^{8}$

"Soane, "A short Anthology of Guran Poetry," in the Journal of the Royal Asiatic Society, 1921, pp. 57-81.

2 Ibn Khallikân, Wafayâtt-utl-A'yân (ed. de Slane), iii, p. 229.

3 Id. ib., iii, pp. 181-2.

Id. ib., i, pp. 272-3.

Id. ib., iii, pp. 101-2.

6 Id. ib., i, p. 197. Similarly, Az-Zâhir, lord of Aleppo, maintained a famous Egyptian historian named Jamâl-ud-Dîn ibn-ul-Qufṭ̂i in his service (Abu-'l-Faraj, p. 521).

7 Id. ib., ii, pp. 188-90. After studying at Maușil he migrated to Jerusalem and taught in the Madrasat-us-Sâlihiyah ; in A.D. 1209 he moved to Damascus, where he taught as a Shâfi' professor, and in A.D. 1243 became head of the madrasat-rlAs̆hrafîyah, founded by Sitt-ush-Shâm, the sister of Saladin (Abu-'l-Fidâ, Annals, ed. Reise, vol. iv, pp. 466, 481 ; Brockelmann, op. cit., vol. i, pp. 358-60).

${ }^{8}$ Ibn Khallikân, ii, pp. 430-1 ; Ibn-ul-Athîr, Kâmil, xii, p. 27; Abu-'l-Fidâ, iv, p. 103. The Kurds seem about this period to have been enthusiastic over the science of canon-law, for Abü Shâmah records a dispute at Maușil between the Arab and Kurdish parties which became so violent that Nûr-ud-Din had to summon the disputants to Aleppo and settle it by putting in the hands of each side a school in which they could expound their own peculiar doctrines (Kitâbur-Radatain, in the Recueil, vol. ir, p. 28). 
Of the three greatest Kurdish writers, Abu-'l-Fidâ, the Aiyûbî prince of Hamâh, wrote a geography, a history of pre-Islamic times, and a book of Annals from the time of Muhammad down till his own death; but, like most of the Arabic historians, his works are to a large extent compilations and abridgments of earlier chronicles, with little or no endeavour to weigh evidence or test the value of his sources, and his geography only gives yet another account of places and countries which had been visited and fully described by his more famous predecessors. He, too, wrote in Arabic, the language of the educated and learned classes of his day. ${ }^{1}$ Of Idrîs ${ }^{2}$ and Sharaf-ud-Dîn, the historians, more will be said hereafter, when some account is given of their lives and the times in which they lived.

The Kurdish language has never been reduced to writing, and this is doubtless one of the reasons why it has never been employed in literature. Thus most Kurds, who felt themselves inspired to write histories or books on geography, were compelled, if they used Kurdish, to employ the Arabic script; they therefore avoided the difficulty of adapting a foreign alphabet to their own language by adopting the natural expedient of writing in Arabic, a language moreover infinitely richer in resources and already fully developed by its long employment in Muslim literature.

Apart from these three well-known authors, who wrote in Arabic, a few Kurdish writers and scholars have at various times composed works in their native tongue. 'Alî Harîrî (A.D. 1009-10-A.D. 1080-1), a native of Harîr in the Hakkârî district, left a collection of poems well known in Kurdistân. Malâ'î Jizrî, whose true name was Shaikh Aḥmad (A.D. 1078-9-A.D. 1160-1) and who was born in Bukhtân, fell in love with the sister of the amir of his tribe and wrote in her honour poems much admired by the Kurds of his day ; yet he is said to have refused the hand of the princess in marriage as too great an honour for one of humble birth. Muhammad, surnamed Faqîh Tairân (A.D. 1302-3-A.D. 1375-6), who was sprung from the town of Makas, left at his death a number of tales and many poems written in a choice but florid style. Malâ'î Aḥmad (A.D. 1417-8-A.D. 1494-5), an inhabitant of the Hakkârî country, left many verses collected into a dîwin or anthology and a brochure in Kurdish entitled Maulutd or

1 On the writings of Abu.'I-Fidà, see Brockelmann's Geschichte der Arabischen Literatur, vol. ii, pp. 44-6. His history is called the Mfukhtasar Tarikh-il-bashar and his geography the Taqwin-ul-Buldân.

2 See Brockelmann, op. cit., vol, ii, p. 233.

VOL. II. PART III. 
the "Birth of Muhammad", which attained great fame in Kurdistân. Ahmmad Khân, of the Khâniyân Kurds, a clan of the Hakkârî tribe, who settled at Bâyazîd in A.D. 1591 or 1592, was the author of some love-poems, a small glossary of select Kurdish and Arabic words, and of a large collection of Kurdish, Turkish, and Arabic poets; he was versed also in other arts as well as in natural science, and died in A.D. 1652 or 1653. Ismâ'îl (A.D. 1654-5-A.D. 1709-10), of Bâyazîd, compiled a small Kurmânjî-Arabic-Persian glossary for the use of the young, entitled the Gulzân, and several slight poems in Kurdish. Sharif Khân (A.D. 1689-90-A.D. 1748-9), a prince of the Hakkârî born at Jûlamarik, left some poems both in Kurdish and in Persian. Murâd Khân (A.D. 1737-8-A.D. 1781-5), also of Bâyazîd, wrote several erotic pieces and other fugitive compositions in kurmanjî. ${ }^{1}$ With Murâd Khân all attempts at literary composition appear to have died out, and the careful researches of modern scholars have only brought to light the songs and tales of a national folk-lore. ${ }^{2}$

Very few Kurds at the present time are in the least degree educated, for they have neither the intelligence nor the natural inclination to grasp abstract ideas; their genius, indeed, is practical rather than speculative. Those Kurds who have attained distinction beyond the narrow confines of their own country have all been trained in the American Protestant Colleges at 'Aintâb, Bairût, or Constantinople, or in any case outside Kurdistân. (The education, moreover, for which they show the greatest aptitude is one with some such practical goal in view as employment in the Civil Service or in the Army. The number of those who have succeeded in deriving benefit from a liberal education is very few, perhaps not a dozen persons now living. Among them may be mentioned five Kurds who have obtained high offices in the Ottoman Government : these are Saiyid 'Abd-ul-Qâdir, General Sharîf Pâshâ, 'Izzat and Sa'îd Pâshâ, and Zakî Pâshâ, of whom the lașt two have held at different times the portfolio of the Minister of the Interior. 'Abd-ul-Qâdir was in exile during the reign of 'Abd-ul-Hamîd, but upon the announcement of the Constitution he was promoted to be a Senator and has been since then President of the Council of State; General Sharîf Pâshâ was formerly the Turkish Minister in Stockholm, after which he became Minister for Foreign Affairs ; and Zakî Pâshâ, surnamed Al-Halabî or "the Aleppine", who was a member of the

I Jaba, Recueil de Notices et Récits Kourdes.

2 See, for example, Prymn and Socin, Kurdische Sammlungen. 
Committee of Union and Progress and a man of moderate views, commanded the Army of Uskub in the Balkan War against the Serbians, when he was driven into Albania, and later preceded Jamâl as the commander-in-chief in Syria, a post which he relinquished to become one of the Kaiser's aides-de-camp in Berlin.

Notes on "The Religion of the Kurds" in Vol. II, Pr. II; PP. 197-213 OF THE BULLETIN

p. 200.-Yazînî. Another derivation of the name is that implied by Ash-Shahrastânî (Kitâb-ul-Milal wa-'n-Nihal, Cureton, vol. i, p. 101), who says that the Yazîdî were the followers of Yazîd ibn Unaisah, who took a prominent part in the religious quarrels of the first century of Islâm and who was an adherent of the first Mụakkamah and afterwards of the Ibâlîyah; he believed that God would send an apostle from among the Persians and reveal to him a book already written in heaven, so that he would forsake Islâm and join the Sabians. This prophet Kremer (in the Geschichte der herrschenden Ideen des Islams, p. 195) identified with the Shaikh 'Adî, but wrongly, for the Shaikh was a Syrian from Ba'albakk. From these facts Isya Joseph (in the American Journal of Semitic Languages, vol. xxv, pp. 115-18) concluded with Ash-Shahrastânî that the Yazîdî were originally a sub-sect of Khârijî, akin to the Ibâḷîyah, named after their founder Yazîd ibn Unaisah, and that, having migrated in the fourteenth century (Layard, Nineveh and its Remains, vol. ii, p. 254), they were drawn into the movement of which the Shaikh 'Adî was the moving spirit and ended by regarding him after his death as a saint and later as the incarnation of God; (see also Siouffi in the Joumal Asiatique, vin, v, p. 80).

p. 201.-MALIK '? Â' ÛS. According to Lidzbarski (in the Zeitschrift der Dautschen Morgenländischen Gesellschaft, rol. lv, p. 592, n. 1) the name of the Yazîdi god is to be traced back to a god called 'Tâ'uz, to whom Muhammad ibn Ishââ bəars witness (in the Fihrist, Flügel, Ix, v, 4, pp. 322-3); for in an account of the gods and festivals of the Sabians

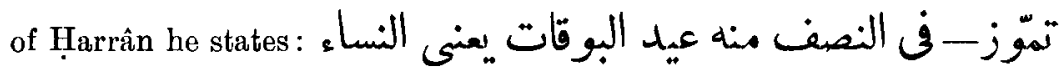
" "Tammuz: in the middle thereof is the feast of Al-bûqât, namely of the Weeping Women [a statement philologically doubtful], that is Tâ'uz, a feast which is held in honour of the god Tâ'uz." Now the identification of the Yazîdî Tầ' ûs with the 'Tâ'uz of the people of Harrân is very likely: for (1) the 
Yazîdî and the Harrânî were close neighbours and the religion of the Yazîdî is known to have been tainted with Sabian influence, and (2) the little-known Tâ'uz would easily have been assimilated to the Arabic Tâ' ûs, "peacock," in consequence of which corruption the inage of that bird would naturally be introduced into their worship. But the same passage carries the inquiry a step further, for in it the god 'Tâ'uz is identified with Tammuz, a conclusion regarded as probable also by Ch wolsohn after an examination of various alternatives (in Die Ssabier, vol. ii, pp. 204-5). This, in spite of Isya Joseph (in the American Journal of Semitic Languages, vol. xxv, p. 250), has much in its favour: (1) the derivation both of the Malik 'Ta'ûs and of Tâ'uz from a god whose worship was so well-known and widely spread as that of Tammuz is intrinsically probable; (2) the interchange of $n$ and $w$ is not unknown in Kurdish (cp. Justi, Kurdische Granmatik, p. 82) and common in the eastern Semitic dialects; cp. Ass. Dummn̂zu and Du'ûzu for Tammuz (Muss-Arnolt, Assyrisches Handwörterbuch, p. 236a) and the similar weakening of Shamash into Shawash in Aramaic (Delaporte, Epigraphes Araméens, p. 17).

The view put forward by Professor Jackson (in the Journal of the American Oriental Society, vol. xxv, p. 178) that the cult of the Malik Tâ'ûs is to be referred to old devil-worship in Mâzandârân has little to recommend it: for, (1) there is no trace of devil-worship in connexion with the Malik Tâ' ûs; (2) there is no evidence, apart from the proposed derivation of "Yazî̀n̂" from the term of Yazd, of a Persian origin of this religion; (3) it fails to account for the name Malik Tấ' n̂s. See also, on the Yazîdî religion, Jalâl Nûrî, Le diable promu 'Dieu', essai sur le Yézidisme (Constantinople) and Anastasie Marie in Al-Mashrik, vol. ii, pp. 32-7, 151-6, 309-14, 395-9, 547-53, 615-55, 731-6, and 830-6, as cited by Bittner (loc. cit. infr.).

p. 201, n. 2.- Rașî̀y. Professor Bevan (in a private communication) points out that this should be rajim (Eth. rĕgüm), "accursed," which Muslim commentators wrongly took to mean "stoned" (Nöldeke, Neue Beiträge zur Senitischen Sprachwissenschaft, p. 47).

p. 202.-Professor Bevan points out that it is the ordinary Muslim doctrine that Christ was not crucified (Qhî' $a n$, iv, 156).

p. 203, 1. 15.-For "battle" read "wattle".

p. 204.-AL-JALWAH AND MUṢGa-Ur-RAsh (not Nushaf-ul-Rash). A text of these books has been published from a MS. obtained in Mausil by Isya Joseph (in the American Journal of Semitic Languages, vol. xxv, pp. 111-56) as well as a translation with brief notes (ibid., pp. 218-54). The MS. contains these two books together with an introduction and an appendix, which consists of a collection of materials concerning the faith and practice of the Yazîdî, a poem in praise of the Shaikh 'Adî, the 
principal prayer of the Yazîdî in Kurdish, a description of their priestly system, and the petition to the Ottoman Government (on which see the Bulletin, vol. ii, pt. ii, pp. 207-10). Of Al-Jalwah, which is said to have been dictated by the Shaikh 'Adî himself to his secretary Shaikh Fakhr-ud-Dîn in A.D. 1162-3, the original is now kept at Ba'idri. The "Black Book" claims to have been written by one Hasan-ul-Bașrî in A.D. 1342-3, and the original is preserved at Qaṣr 'Izz-ud-Dîn, a village on the east side of the Tigris; it derives its name from the description in it of the descent of the Lord upon the Black Mountain. But the authenticity of these books is a matter of some doubt. Other Yazîdî MSS. are known: two are in the Bibliotheque Nationale at Paris (Fond Syriaque, Nos. 306 and 325), part of which has been translated by Professor E. H. Browne in an appendix to O. H. Parry's Six Months in a Syrian Monastery, pp. 357-87; one Syriac text has been published by J.-B. Chabot in the Journal Asiatique, Ix, vii, pp. 100 ff., and another by Giamil in Monte Singar from a MS. copied for him from an original in the monastery of Rabban Hurmuzd. The latter is the work of a Syrian priest named Isaac who had lived for a long while among the Yazîdî and who wrote his work in the form of a catechism, in which a youthful Yazîdî questions one of his teachers about his faith; the author, however, occasionally drops his rôle, so that the questioner is seen to be none other than Isaac himself (Joseph, loc. cit.). On the sacred books of the Yazîdî see also M. Bittner in Denkschriften der kais. Akademie der Wissenschaften in Wien, phil.-hist. Klasse, LV, iv, pp. 1-97, and v, pp. 1-18, and Anastasie Marie in Anthropos, VI, i, pp. 1-39.

p. 210.-Fourteenth Clause. The Şabians also did not eat purslane, garlic, beans, cauliflower, cabbage, and lentils (Bar Hebræus, At-Tarîkh p. 266, cited by Joseph, loc. cit., p. 254). 